\title{
Fish metacommunity structure in Caño Maraca, an important nursery habitat in the Western Llanos of Venezuela
}

\author{
Kirk O. Winemiller' ${ }^{1}$, Donald C. Taphorn ${ }^{2}$, Leslie C. Kelso-Winemiller ${ }^{3}$, \\ Edwin O. López-Delgado ${ }^{1}$, Friedrich W. Keppeler ${ }^{1}$ and Carmen G. Montaña ${ }^{4}$
}

We investigated spatial and seasonal variation of fish assemblages of Caño Maraca, a creek in Venezuela's Western Llanos, a region with strong wet-dry seasonality. Fishes were surveyed over a 19-year period at three sites along the longitudinal gradient: a headwater site with a narrow channel, a middle site with shallow channels traversing a seasonal wetland, and a lower site where the channel has higher banks. Assemblage composition and presence of species with juveniles and various life history strategies were compared during wet and dry seasons. Overall, fish species richness was lowest at the headwater site and highest at the downstream site. During the wet season, however, species richness is greatest at the middle site, a pattern associated with migration into the site for reproduction and use of the wetland as a nursery. During the dry season, species richness is greater at the downstream site where habitat quality is sufficient to provide suitable habitat for many species. Fish movements and population dynamics in Caño Maraca respond to seasonal environmental changes, and the fish metacommunity appears influenced by species sorting (habitat selection), mass effects (source-sink dynamics), patch dynamics (interspecific differences in colonization and species interaction) as well as random factors (dry-season strandings).

Keywords: Dispersal, Fluvial gradient, Freshwater fish, Neotropics, Nestedness.

Investigamos la variación espacial y temporal de los ensambles de peces en el Caño Maraca, un arroyo localizado en los Llanos Occidentales de Venezuela, región caracterizada por una fuerte estacionalidad húmedo-seco. La ictiofauna fue evaluada en intervalos durante un período de 19 años, en tres sitios a lo largo del gradiente fluvial longitudinal: El primer sitio en la cabecera con un canal estrecho e hidrología estable, el segundo, intermedio con canales poco profundos atravesando un humedal estacional y el ultimo en la zona baja donde el canal tiene bancos más altos. La composición del ensamblaje y la presencia de especies con juveniles y diversas estrategias de historia de vida fueron comparadas durante las estaciones húmedas y secas. En general, la riqueza de especies de peces fue menor en el sitio de la cabecera y más alta en el sitio aguas abajo. Sin embargo, durante la época húmeda, la riqueza de especies fue mayor en el sitio central, patrón asociado con la reproducción de peces y el uso del humedal como criadero. Durante la época seca, la riqueza de especies fue mayor en la zona baja donde la calidad del hábitat es suficiente para proporcionar un hábitat adecuado para muchas especies. El movimiento de los peces y la dinámica poblacional en Caño Maraca están relacionadas a cambios ambientales estacionales. Adicionalmente la metacomunidad de peces parece estar influenciada por el ordenamiento de especies (selección de hábitat), efectos de masas (dinámica fuente-sumidero), dinámica de parches (involucrando diferencias interespecíficas en la tasa de colonización y capacidad competitiva) y factores aleatorios (relacionados con la duración de la estación seca).

Palabras clave: Anidamiento, Dispersión, Gradiente fluvial, Neotrópico, Peces de agua dulce.

\section{Introduction}

Headwater streams typically make up two thirds or more of the total channel length within a drainage network, and small streams are important for maintenance of biodiversity and ecosystem services at regional scales (Freeman et al., 2007). Although understanding of stream ecology in the tro- pics continues to lag behind knowledge from north temperate regions (Winemiller et al., 2008), recent years have seen a great increase in research on fish ecology in Neotropical streams, especially in Brazil (e.g., Abes, Agostinho, 2001; Casatti, 2005; Almeida, Cetra, 2016; Juen et al., 2016). Temperature variation in tropical regions is minimal compared to temperate regions, yet tropical regions often have strong se-

\footnotetext{
${ }^{1}$ Department of Wildlife and Fisheries Sciences, Texas A\&M University, 77843 College Station, TX, USA. (KOW) k-winemiller@tamu.edu, (Dhttps://orcid.org/0000-0003-0236-5129 (Corresponding author), (EOLD) eolopezd@gmail.com, (FWK) kepp1990@tamu.edu

${ }^{2}$ Museo de Ciencias Naturales, Universidad Experimental de Los Llanos Occidentales Ezequiel Zamora, 3310 Guanare, Portuguesa, Venezuela.taphorn@gmail.com

${ }^{3}$ Department of Biology, Texas A\&M University, 77843 College Station, TX, USA. lesliew@bio.tamu.edu

${ }^{4}$ Department of Biological Sciences, Sam Houston State University, 77341 Huntsville, TX, USA. cgm026@shsu.edu
} 
asonal patterns of rainfall (wet/dry seasonality) that strongly influence stream ecology. As for any organism, stream fishes undergo changes in population abundance and spatial distribution as a function of reproduction, mortality and dispersal. These processes are influenced by temporal and spatial variation in habitat quantity and quality, disturbance regime (e.g., flash floods, desiccation, aquatic hypoxia), primary production, inputs of allochthonous materials, predation, and landscape connectivity as affected by local precipitation and hydrology.

Stream physical and biological features vary greatly depending on geology, topography and climate among other regional factors. For example, headwater streams in mountainous regions have high gradients, fast water currents, substrates of exposed bedrock and coarse particles, series of riffles and plunge pools, and fish species adapted to life in fast-flowing water (Lujan, Conway, 2015). In contrast, headwater streams in flatlands have meandering channels, slow water currents, and sandy or silty substrates. These sluggish streams often accumulate large amounts of detritus and in semiarid and arid climates may have reaches that periodically become dry, leaving series of isolated pools. Fish assemblages in low-gradient streams often support fish assemblages that are more taxonomically and functionally diverse compared to those found in higher-gradient streams of the same region (Gonçalves, Braga, 2012; Wolff, Hahn, 2017).

The richness and composition of stream fish assemblages vary in response to longitudinal gradients of stream size and habitat conditions in a fairly predictable manner (Schlosser, 1982). First-order streams in headwaters contain few species that tend to be nested subsets of species that inhabit larger habitats downstream. As channel reaches further downstream become progressively larger with greater habitat heterogeneity, fish species richness and functional diversity increase (Matthews, 1986; Paller, 1994; Súarez, Petrere, 2007). Nonetheless, topography and other watershed features sometimes do not follow a gradual transition from headwaters to higher-order stream reaches, and seasonal variation can influence longitudinal patterns of fish assemblage composition. Low-gradient streams in tropical wet/dry climates undergo particularly strong changes in hydrology and associated environmental conditions and ecological processes. During the wet season, tropical streams spill into flooded savannas or forests into which fishes disperse to exploit food resources and refuges (Lowe-McConnell, 1987). During the dry season, water recedes from floodplains and fishes must return to wetted channels or floodplain pools where they may become trapped as water levels continue to fall. Predator-prey interactions intensify under conditions of high fish density within isolated water bodies, and additional mortality is caused by bird predation and degradation of water quality from low dissolved oxygen and high hydrogen sulfide concentrations derived from microbial metabolism (Winemiller, 1989b, 1990).

Here we report findings from an investigation of seasonal variation in fish assemblage composition at sites along the longitudinal gradient of Caño Maraca, a low-order creek that drains flat terrain in the High Llanos of Venezuela. Caño Maraca and other creeks in the Western Llanos support high fish diversity, with many species important in artisanal fisheries, and understanding factors influencing spatial and temporal dynamics of fish distributions is fundamental for conservation. We analyzed assemblage composition to evaluate predictions about processes structuring metacommunities (Leibold et al., 2004; Winemiller et al., 2010) as well as the degree that local assemblages may be nested along the longitudinal gradient (i.e., revealing a pattern of successive species addition without replacement). Because of strong seasonal changes in precipitation and hydrology affecting aquatic habitat quantity and quality in Caño Maraca, we predicted that fish assemblages would show large seasonal shifts in assemblage composition as fishes disperse and encounter different abiotic and biotic environmental conditions. We also predicted that species richness and community composition might not reveal a strong longitudinal gradient due to similar ranges of habitats at locations throughout the creek's shallow elevational gradient. Longitudinal patterns might be especially weak during the wet season because the creek's middle reach has an extensive wetland that previously was documented to be important for fish reproduction during the wet season (Winemiller, 1989a). If sufficient numbers of species colonize the wetland for reproduction, species richness might be higher in middle than lower reaches. Additionally, we examined seasonal and spatial variation in proportions of species with alternative reproductive strategies and presence of small juveniles as indicators of recent reproduction at the locations. This research advances understanding of species responses to environmental variation at the watershed scale, which is critical for ecosystem-based management of tropical freshwater fishes (Goulding et al., 2018).

\section{Material and Methods}

Study system. Surveys were conducted at three locations in Caño Maraca (Fig. 1) during wet and dry seasons within and among years from 1979 to 1997 . Caño Maraca is a low-gradient creek within the Rio Apure drainage in the state of Portuguesa, Venezuela. The creek drains savannas, scrub forest, remnant forest stands and wetlands within the Western Llanos ("high llanos"), a flat region containing alluvium derived from the Andes Mountains. Fertile soils make the Western Llanos Venezuela's most important region for agriculture. The region receives an average of $1,300 \mathrm{~mm}$ of rainfall per year, with about $850 \mathrm{~mm}$ generally falling between June and September.

The uppermost survey location (Naciente) has a small, well-define channel in the headwaters of Caño Maraca. At this location, the stream is bordered by riparian forest. To the north, the local watershed contains sugarcane fields and canals that drain into Caño Maraca and Caño La Pica (headwater of Caño Igués) at locations further downstream; to the south the watershed is a mosaic of forest, pasture, and crops. 


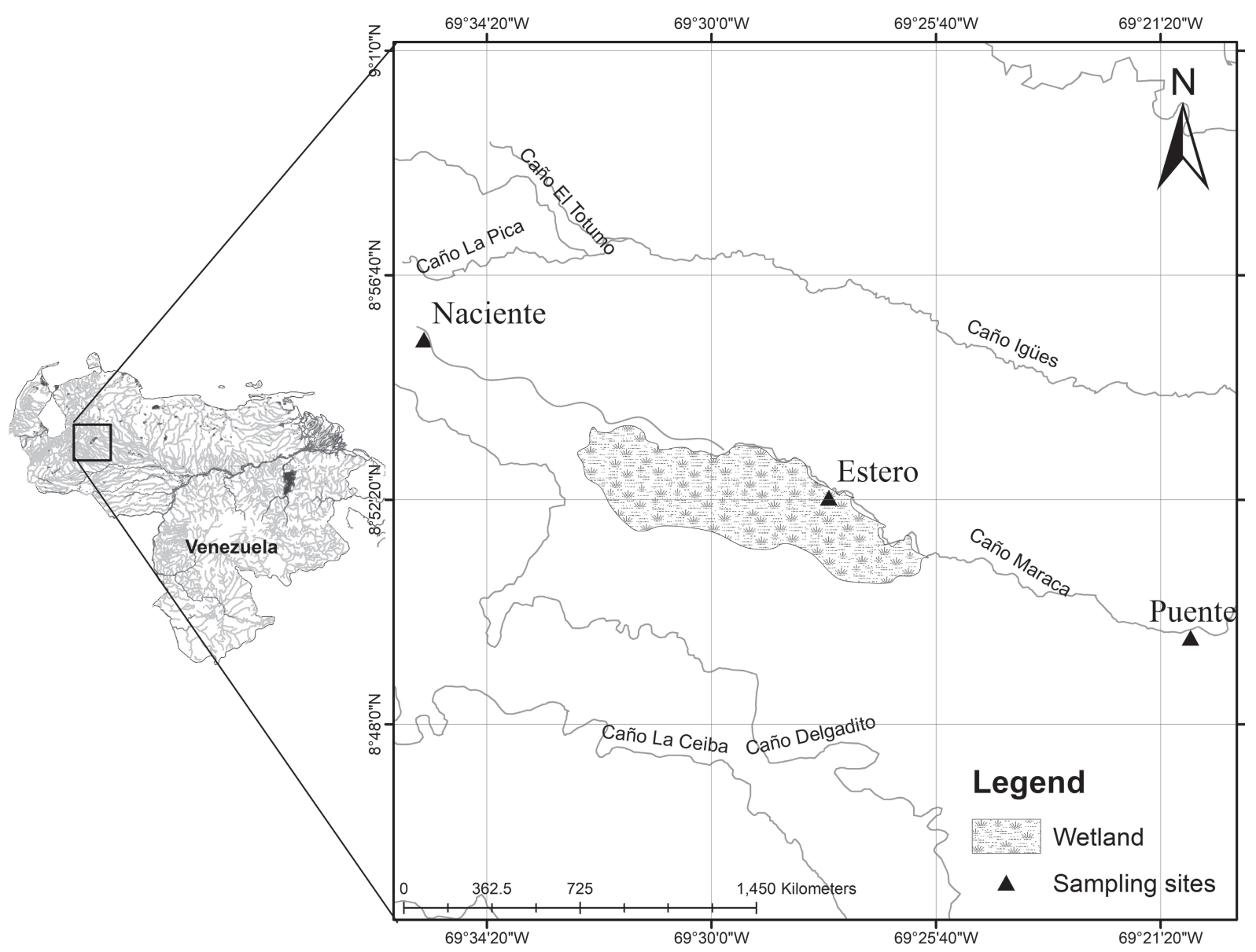

Fig. 1. Map showing location of Caño Maraca within the Orinoco River Basin in Venezuela and locations of three survey sites (triangles).

The middle survey location (Estero) contains an interconnected network of channels and pools within a mostly forested wetland complex. In the Llanos, "esteros" are seasonally flooded, low-lying areas associated with low-order creeks (caños). During the rainy season, these habitats are highly productive, contain extensive beds of submerged, emergent and floating macrophytes, with Eichhornia diversifolia dominant, and provide important habitat for reproduction and early life stages of many llanos fishes (Mago-Leccia, 1970; Taphorn, Lilyestrom, 1985; Winemiller, 1989a). During the peak months of the annual dry season (January-early May), aquatic habitat in the estero is reduced to a series of isolated pools, some of which are covered by a layer of aquatic macrophytes dominated by Pistia stratiotes, Ludwigia helminthorrhiza, Salvinia auriculata, and Salvinia sprucei. Intervals of aquatic hypoxia may occur from late October to early May and appear to be associated with aquatic macrophyte decomposition within the drying floodplain, pools and channels (Winemiller, 1989b).

The downstream survey site was located at a highway bridge crossing (Puente) in a reach with a well-defined channel bordered by grasses, forbs and shrubs, and a sparse gallery forest. The local watershed is dominated by savanna/ shrubland and pasture. The creek channel at Puente main- tains water flow throughout the year. During the wet season, patches of floating macrophytes, especially water hyacinth (Eichhornia diversifolia), drift downstream.

On average, the survey site at Naciente has a narrower channel and coarser substrate than the other two sites, the Estero site has a broader channel, higher water temperature and lower water conductivity, and the Puente site has greater water depth (Tab. 1). The Estero site also has much more extensive aquatic vegetation than the other two sites, especially during the wet season when aquatic habitats were dominated

Tab. 1. Mean and standard deviation (sd) of depth, width, water temperature (Temp), $\mathrm{pH}$, conductivity (Cond) and predominant substrate type at three sites along the longitudinal gradient of Caño Maraca.

\begin{tabular}{clcccccc}
\hline Site & & $\begin{array}{c}\text { Depth } \\
(\mathrm{m})\end{array}$ & $\begin{array}{c}\text { Width } \\
(\mathrm{m})\end{array}$ & $\begin{array}{c}\text { Temp } \\
\left({ }^{\circ} \mathrm{C}\right)\end{array}$ & $\mathrm{pH}$ & $\begin{array}{c}\text { Cond } \\
(\mu \mathrm{S} / \mathrm{cm})\end{array}$ & Substrate \\
\hline \multirow{2}{*}{ Naciente } & mean & 0.8 & 4.0 & 26.3 & 6.80 & 292 & sand \\
& $\mathrm{sd}$ & 0.4 & 2.8 & 0.35 & 0.35 & 11 & gravel \\
\hline \multirow{2}{*}{ Estero } & mean & 0.8 & 17.1 & 30.5 & 6.50 & 144 & clay \\
& $\mathrm{sd}$ & 0.4 & 14.7 & 3.5 & 0.55 & 37 & silt \\
\hline \multirow{2}{*}{ Puente } & mean & 1.6 & 13.7 & 26.2 & 6.50 & 240 & clay \\
& sd & 0.4 & 7.1 & 1.3 & 0.50 & 118 & silt \\
\hline
\end{tabular}


by submerged, emergent and floating beds of diverse aquatic macrophytes. At all three locations, maximum water current velocity measured at the thalweg was nil during the dry season and moderate $(0.20-0.33 \mathrm{~m} / \mathrm{s})$ during the wet season.

Field surveys. Surveys were conducted at Naciente on November 4, 1984 (dry season) and August 2, 1997 (wet season), at Estero on 9 dates in the dry season and 10 dates in the wet season, and at Puente on 6 dates during the dry season and 5 dates during the wet season. Fishes were collected at each site during each survey using seine nets with $3 / 8$ " mesh, the dimensions of which varied depending on water depth, channel width and density of aquatic macrophytes. Seine hauls were conducted until three consecutive hauls yielded no additional species in the sample. At Estero and Puente, the seine also was rolled onto poles, pushed beneath mats of floating vegetation, and then raised while enveloping vegetation and fishes resident within it.

Specimens were identified to genus and species and counted, and subsets of each collection were fixed in $15 \%$ formalin solution, then preserved in 75\% ethanol and archived in the ichthyology collection of the Museo de Ciencias Naturales, Universidad Experimental de Los Llanos Occidentales Ezequiel Zamora, Guanare, Venezuela. The presence of any small juvenile specimens indicative of recent reproduction was recorded for each collection. In 1984, fishes were surveyed monthly at the Estero site to provide material for detailed study of fish reproduction (Winemiller, 1989a) and food web ecology (Winemiller, 1990) and other topics (Winemiller, 1989b; Winemiller, Pianka, 1990).

Data analysis. Surveys were directed by either the first or second author, but field assistants and total survey effort varied dependent upon environmental conditions and the criterion described above for termination. Species presence/ absence data were used for ordination and rarefaction analyses. To test for differences in species richness between locations, we performed rarefaction of species incidence using Hill numbers (Chao et al., 2014). Hill numbers are a family of diversity indices that are parameterized by an order q. As the order $\mathrm{q}$ increases, so does the sensitivity to species relative abundance (for presence-absence data, the incidence is a measure of species abundance/dominance). Here, rarefactions were performed using the first Hill number (0), which is analogous to species richness. Short-range extrapolation and $95 \%$ confidence intervals were calculated for each location. To explore how seasons might affect rarefaction curves, we conducted separate analyses for wet and dry seasons as well as for all survey dates combined. The rarefactions using Hill numbers were conducted in $\mathrm{R}$ ( $\mathrm{R}$ Core Team, 2017) with the package iNEXT (Hsieh et al., 2016).

Redundancy analysis (RDA) was performed to explore the effect of location, season and their interaction (factors) on species composition (response variable). Year of survey was used as a conditioning variable to control for inter-annual variation in assemblage composition. We chose RDA rather than other constrained ordination methods because: 1) RDA is suitable to analyse presence/absence data for assemblage composition (Legendre, Gallagher 2001), and 2) RDA allows for control of potential confounding variables (i.e., Year). An ANOVA-like permutation test was performed to test the statistical significance of each factor. This test computes a Pseudo-F statistic (ratio of constrained and unconstrained total inertia, each divided by their respective ranks; Oksanen et al., 2017) of permuted response data ( $\mathrm{N}$ of permutations $=999)$ with the original data. More details can be found in Legendre, Legendre (2012). Both the RDA and permutation test were conducted using the R package Vegan (Oksanen et al., 2017).

To identify the species most common at locations during each season, the indicator species method proposed by Dufrêne, Legendre (1997) was performed using species relative abundance data. The indicator value of a species is calculated as the product of its average abundance and frequency in each season and yields values that can range from 0 (no value as an indicator) to 1 (perfect indicator). The significance test for this method uses the difference between the observed value and the mean of the values obtained from 1,000 randomizations. Species indicator analysis was conducted using the package labdsv in R (Roberts, 2016).

In order to visualize patterns of species spatial distribution, including nestedness, during wet and dry seasons, species present at each location were plotted as shaded rectangles using the function imagine from the metacom package in R (Dallas, 2018).

To test for associations between reproductive ecology and seasonal variation in conditions at the three sites along the longitudinal fluvial gradient, species were assigned life history strategies based on findings of a study conducted at the Estero site by Winemiller (1989a) and classifications reported therein. Based on multivariate analysis of 10 life history variables, that study revealed three endpoint strategies - opportunistic (small fishes with early maturation, high reproductive effort, and long reproductive periods), equilibrium (small to medium-sized fishes with low fecundity, large eggs, and well-developed parental care), and seasonal (medium to large fishes with high fecundity, small eggs, no parental care, and short spawning periods; this strategy was later labeled "periodic" by Winemiller (1992) and Winemiller, Rose (1992)). Species spanned a continuum of strategies within a triangular surface defined by constraints between size at maturation, batch fecundity and investment per offspring (log[egg size + degree of parental care]), and Winemiller (1989a) assigned each species at Caño Maraca to one of the three life history categories based on their relative positions along gradients for these three variables.

\section{Results}

Surveys yielded a total of 21 fish species at Naciente, 84 species at Estero, and 96 species at Puente, with characiform fishes, especially characids, dominant at all three locations 
(S1 - available only as online supplementary file accessed with the online version of the article at http://www.scielo.br/ ni). When all available data for each site were combined and species richness values adjusted for survey effort via rarefaction, species richness varied according to the longitudinal fluvial gradient, with lowest richness at the headwater site (Naciente) and highest richness at the site located furthest downstream (Puente) (Fig. 2). This pattern also was observed during the dry season, although there were insufficient samples for Naciente to perform rarefaction. During the wet season, however, the wetland location in the middle section (Estero) had highest species richness (Fig. 2).

RDA ordination of fish assemblage composition revealed separation of the three sites along gradients described by the first two canonical axes (Fig. 3; see $\mathbf{S 2}$ - available only as online supplementary file accessed with the online version of the article at http://www.scielo.br/ni - for associated statistics). The first two axis of the model including location and season explained $21.8 \%$ of total variation (axis $1=15.9 \%$, axis $2=5.9 \%$ ). Whereas season was not a significant predictor of assemblage composition $(\mathrm{F}=1.19, P=$ $0.23)$, location ( $\mathrm{F}=3.97, P<0.01)$ and the interaction between season and location were significant $(\mathrm{F}=1.40, P=0.05)$. The ordination was most strongly influenced (species with goodness of fit $>0.4$ ) by Apistogramma hoignei Meinken, 1965, Brachyhypopomus sp. (all with positive loadings on both axis 1 and 2), Astronotus ocellatus (Agassiz, 1831), Cichlasoma orinocense Kullander, 1983, Ctenobrycon spilurus (Valenciennes, 1850), Gymnotus carapo Linnaeus, 1758, Hoplias malabaricus (Bloch, 1794), Pyrrhulina lugubris Eigenmann, 1922 (positive loadings on axis 1, negative loadings on axis 2), Farlowella sp., Moenkhausia dichroura (Kner, 1858), Paragoniates alburnus Steindachner, 1876 (negative loadings on both axis 1 and 2). Brycon whitei Myers, Weitzman, 1960, Hypostomus sp., and Pimelodus blochii Valenciennes, 1840 had negative loadings on axis 1 and positive loadings on axis 2; however, goodness of fit was low, suggesting that these species had relatively weak influence on the ordination. Within the RDA ordination, local species assemblages at Naciente and Puente revealed less seasonal variation compared to the assemblage at Estero; however, only two collections were made at Naciente. Assemblage composition was strongly divergent at Estero between dry and wet seasons, especially with regard to RDA axis 1 (Fig. 3).

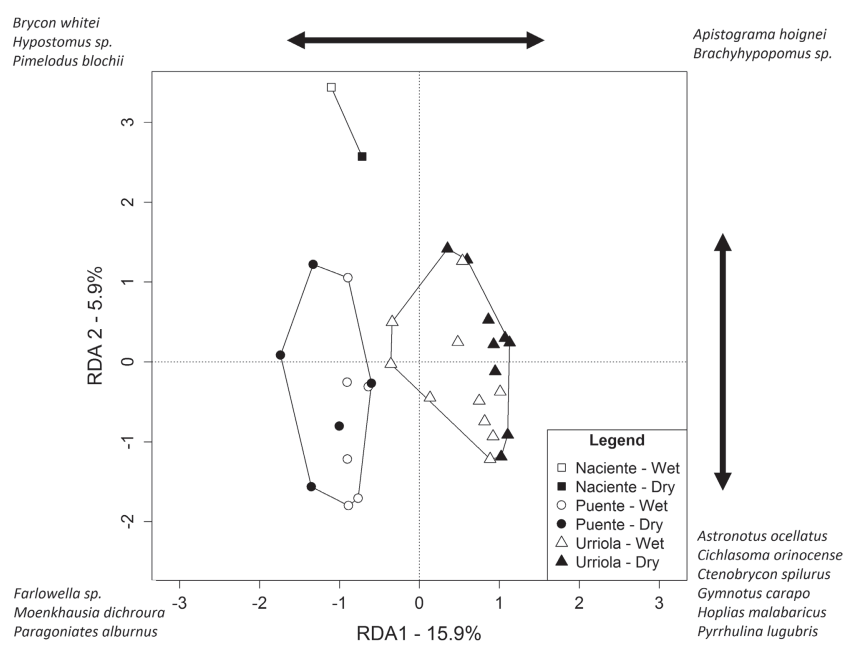

Fig. 3. RDA ordination plot for species assemblages at three sites along the longitudinal gradient of Caño Maraca during dry and wet seasons. Arrows indicate gradients contrasting species with highest positive and negative loadings on each axis.

Indicator species analysis did not reveal any species that were indicators for the fish assemblage at Naciente. For Estero, five species were statistically significant indicators for Estero during the dry season, and a different five species were indicators during the wet season (Tab. 2). Two siluriform species were significant indicators for Puente during the dry season, and four species were indicators for Puente during the wet season (Tab. 2).
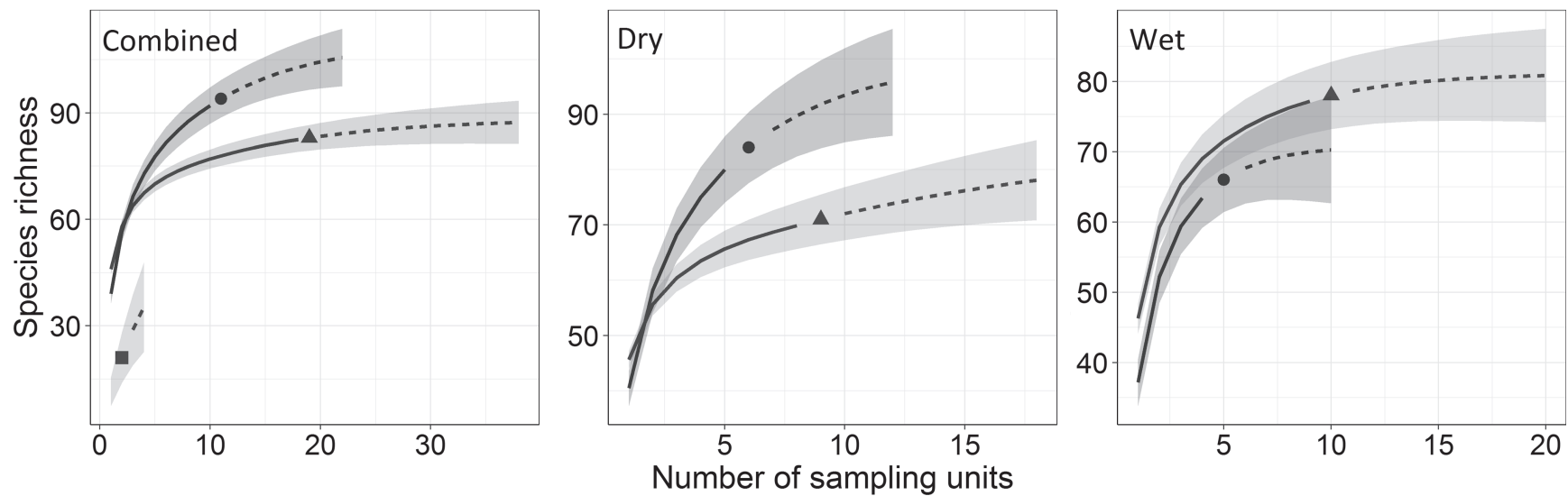

Naciente $\boldsymbol{\Delta}$ Estero Puente - Interpolation .... Extrapolation

Fig. 2. Rarefaction curves with extrapolations for fish assemblages at two survey sites (circle- Puente, triangle- Estero) during dry and wet seasons and all periods combined (square- Naciente) (Hill's number order q=0). 
Tab. 2. Summary of indicator species for sites along the longitudinal gradient of Caño Maraca during dry and wet seasons. Only species with statistically significant values ( $p$ $<0.05$ ) are shown; indicator values range from 0 to 1 , with 1 representing a perfect indicator of a site and season.

\begin{tabular}{llcc}
\hline \multicolumn{1}{c}{ Species } & Site & Season & Indicator value \\
\hline Brachyhypopomus sp. & Estero & Dry & 0.84 \\
Apistogramma hoignei & Estero & Dry & 0.81 \\
Pyrrhulina lugubris & Estero & Dry & 0.77 \\
Hoplosternum littorale & Estero & Dry & 0.73 \\
Ancistrus triradiatus & Estero & Dry & 0.62 \\
\hline Roeboides dientonito & Estero & Wet & 0.76 \\
Knodus alpha & Estero & Wet & 0.70 \\
Serrasalmus irritans & Estero & Wet & 0.70 \\
Rachovia maculipinnis & Estero & Wet & 0.60 \\
Pimelodus blochii & Estero & Wet & 0.50 \\
\hline Ageneiosus magoi & Puente & Dry & 0.83 \\
Corydoras septentrionalis & Puente & Dry & 0.80 \\
\hline Hypoptopoma spectabile & Puente & Wet & 0.92 \\
Characidium sp. G & Puente & Wet & 0.84 \\
Markiana geayi & Puente & Wet & 0.80 \\
Cheirodontops geayi & Puente & Wet & 0.78 \\
\hline
\end{tabular}

Fish assemblages revealed nestedness along the longitudinal fluvial gradient (Fig. 4), with the Naciente assemblage being strongly nested within those of the other two sites. Naciente had one unshared species during the dry season $(\mathrm{Pa}$ rodon apolinari Myers, 1930) and none that were not shared with Estero during the wet season. During the dry season, Estero and Puente samples shared 57 species, with Estero samples having 14 additional unshared species, and Puente samples having 27 unshared species. During the wet season, these samples from these locations shared 57 species, but not all were the same ones shared during the dry season. Three species that were collected at Puente but not Estero during the dry season [Mylossoma albiscopum (Cope, 1872), Pimelodus blochii, and Farlowella sp.] were collected at the latter site during the wet season, and $B$. whitei was collected at $\mathrm{Na}$ ciente during the wet season. During the wet season, Estero samples had 18 species that were not collected at Puente, and Puente samples had 9 unshared species, only one of which (Hemigrammus marginatus Ellis, 1911) was collected during the dry season at Estero where it was rare.

Juvenile specimens of only a few species were collected during the dry season at all three sites (Tab. 3). The number of species with juvenile specimens at Naciente increased from 2 (dry) to 5 (wet), a $150 \%$ increase. At Estero the number of species with juvenile specimens increased from 4 in the dry season to 60 in the wet season $(1,400 \%$ increase), and at Puente the number of species with juveniles increased from 3 in the dry season to 33 in the wet season ( $1,000 \%$ increase).

The number of species classified as opportunistic strategists increased slightly at all three sites during the wet season, and the number of equilibrium strategists was not

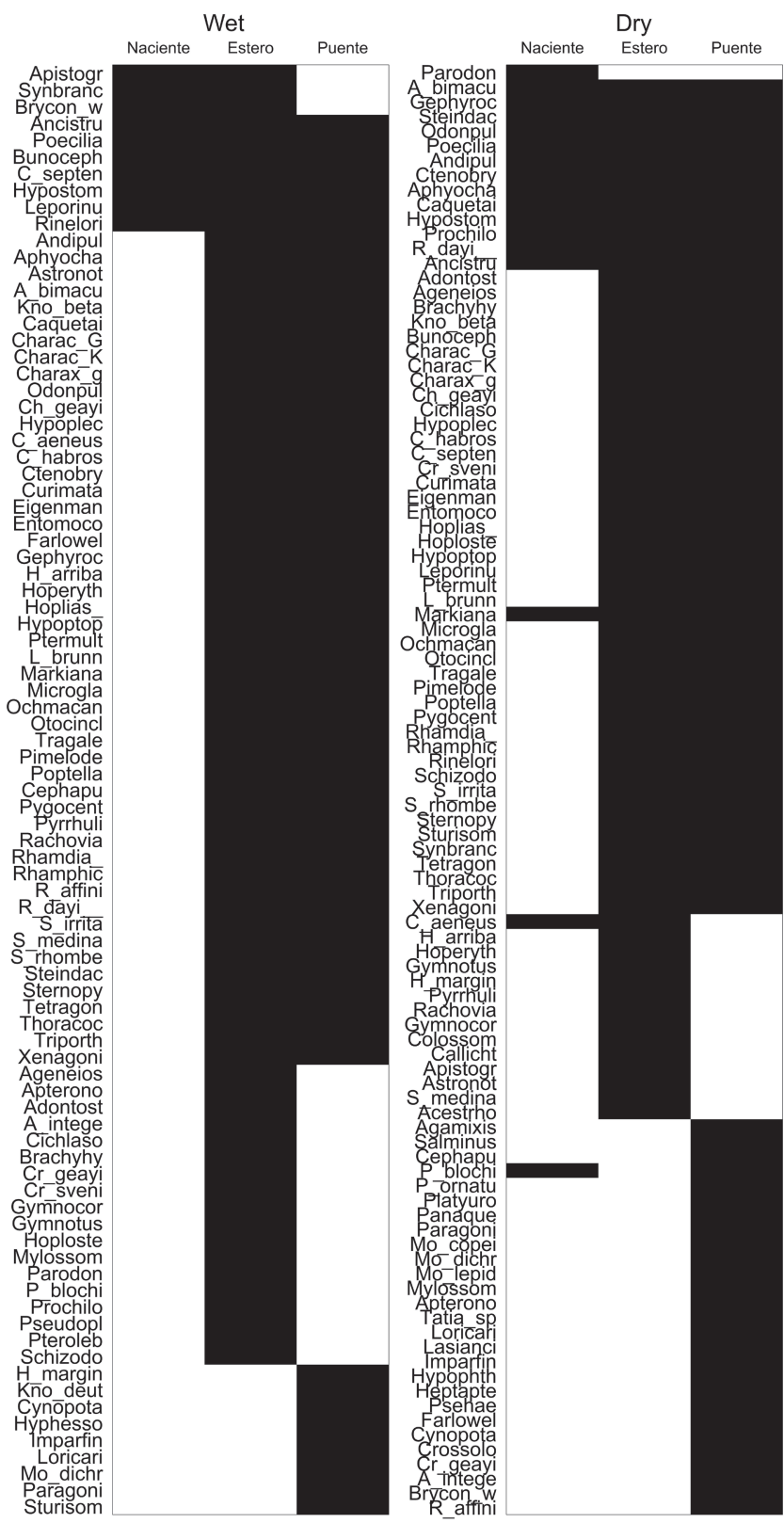

Fig. 4. Summary of species present at Caño Maraca survey sites during dry and wet seasons.

different between dry and wet season samples from either Naciente or Estero (Tab. 3). At Puente, the number of equilibrium strategists was 35\% less during the wet season compared to the dry season. Greatest seasonal shifts were observed for periodic strategists. Wet season samples had 56\% and 23\% fewer periodic strategists at Naciente and Puente, respectively (Tab. 3). In contrast, wet season samples at Estero had $13 \%$ more periodic strategists.

\section{Discussion}

Longitudinal gradient. Overall, the three sites reflect the common pattern of species richness along longitudinal fluvial gradients, with a largely nested pattern of successively 
Tab. 3. Nnumber of species in samples from the dry and wet seasons at three locations along the longitudinal gradient of Caño Maraca. Numbers for juveniles are based on occurrence of at least one juvenile specimen of the species in collective samples for a given season; total number of species is the raw value (non-rarefied) based on presence of either adults or juveniles in collective samples; species life history classifications appear in Tab. S1 - available only as online supplementary file accessed with the online version of the article at http://www.scielo.br/ni.

\begin{tabular}{lccccccccc}
\hline & \multicolumn{2}{c}{ Naciente } & & \multicolumn{2}{c}{ Estero } & & \multicolumn{2}{c}{ Puente } \\
\cline { 2 - 3 } & Dry & Wet & & Dry & Wet & & Dry & Wet \\
\hline Number of species with juveniles & 2 & 5 & & 4 & 60 & & 3 & 33 \\
Total number of species & 17 & 10 & & 71 & 78 & & 84 & 66 \\
Number of opportunistic strategists & 4 & 2 & & 9 & 10 & & 8 & 10 \\
Number of periodic strategists & 9 & 4 & & 45 & 51 & & 56 & 43 \\
Number of equilibrium strategists & 4 & 4 & & 17 & 17 & & 20 & 13 \\
\hline
\end{tabular}

fewer species at sites located further upstream. Species richness estimates for the uppermost location, Naciente, should be interpreted with caution given the low number of surveys. Nonetheless, Naciente had a smaller channel and less aquatic habitat compared to the two downstream sites, and considering also its position in the headwaters, that site would be expected to have lowest species richness. Only one species ( $P$. apolinari) was unique to the headwater stream, Naciente. Parodon apolinari is a benthic characiform (Parodontidae) that grazes on epilithic biofilm, and thus requires habitat with rocky substrates. The substrate at Naciente had a mixture of sand, gravel and small stones. The two downstream sites had few stones, and substrates were dominated by clay and silt. During the dry season, the water at Estero and Puente often is turbid with suspended clay and silt, largely a result of bioturbation by fishes crowded within shrinking aquatic habitats within channels and floodplain pools. These conditions further reduce the suitability for $P$. apolinari and other fishes that inhabit clear streams with coarse substrates.

Whereas species richness was highest at the most downstream location (Puente) when samples from all periods were combined, this pattern did not hold for the wet season. This finding contrasts with those from a study by Súarez, Petrere (2007) who found strong longitudinal patterns of species distribution in two rivers in the Rio Paraná Basin, Brazil, but relatively low seasonal variation. Sufficient numbers of fish species migrate into the Estero location during the wet season to elevate its species richness above that of the downstream reach. We documented the greatest number of juvenile fishes at the Estero site, and Winemiller (1989a) described fishes with diverse life history strategies using this area for reproduction and nursery habitat during the wet season (data from those surveys were included in the database compiled for this study). Juveniles of at least 78 fish species feed on abundant microcrustaceans and other small aquatic invertebrates among new growth of aquatic vegetation in the flooded wetland. At Puente, 18 fewer species were documented during the wet season compared to the dry season, and some of these species were present in Estero samples from the wet season. The reverse trend in total species numbers is observed during the dry season, with the Puente site having more species than the Estero site. Apparently, deeper aquatic habitats with better water quality in the more restricted channel at Puente provide dry-season refuges for many Llanos fishes. Similarly, the headwater stream, Naciente, also had water with good quality during the dry season, and therefore provides dry-season refuge habitat for a relatively small number of species that reside there year-round or migrate seasonally into the site.

In reviewing human impacts to fishes of the Western Llanos, Winemiller et al. (1996) stressed the importance of deep channels as dry season refuges that sustain fish stocks. Throughout the dry season, fishes become increasingly concentrated within shrinking water bodies with declining water quality. Consequently, mortality is naturally high during this period. With the return of rains, flooding and a pulse of aquatic primary and secondary production in expansive wetlands scattered throughout the Western Llanos, remnant stocks rebuild rapidly each year. The life history strategies of species inhabiting this region are well adapted to this seasonal cycle of boom and bust. Small opportunistic strategist, such as annual killifish (Rachovia maculipinnis (Radda, 1964)), guppies (Poecilia reticulata Peters, 1859), and small characids (e.g., Gephyrocharax valencia Eigenmann, 1920, Odontostilbe pulchra (Gill, 1858)) have high reproductive effort and short generation times, traits that contribute to a great capacity for rapid population growth (Winemiller, 1989a; Winemiller, Rose, 1992). Many of these opportunistic strategists have reproductive seasons that extend well into the dry season, and some, such as the guppy, produce offspring throughout the year. These small fishes produce multiple generations per year, and can colonize new flooded habitats and rapidly increase their populations.

Sixty-five percent of the fish species captured in the wetland (Estero) during the early wet season were periodic strategists. Periodic strategists varied in size of maturation, and included all of the largest species in Caño Maraca. Periodic strategists have high batch fecundity, small eggs, no parental care of eggs or larvae, and relatively brief, synchronized spawning periods. Some periodic strategists, such as $B$. whitei and P. mariae, undergo seasonal, long-distance migrations that may extend from the Llanos to streams at middle elevations of the Andes Mountains. The periodic strategy exploits relatively large-scale spatio-temporal variation in environmental quality to enhance recruitment success (Winemiller, 1989a; Winemiller, Rose, 1992). During the early phase of the wet season, the expansive and productive aquatic habitats of newly flooded wetlands at the Estero site provide favorable conditions for survival of unprotected eggs and larvae of periodic strategists. Recruitment success for these species is a function of timing of spawning, the extent and duration of nursery habitat, and connectivity of the system within the drainage network that allows young-of-year 
fishes to escape drying wetlands and seek suitable dry-season refuges. Unlike species classified as opportunistic and equilibrium strategists, which tended to remain at the Estero site during both seasons, the number of periodic strategists declined at that site during the dry season.

Equilibrium strategists comprised $20-24 \%$ of the species at all three sites during both seasons, the only exception being Naciente during the wet season when they comprised $40 \%$. Cichlids and loricariid catfishes, species with large eggs, relatively low batch fecundity and well-developed parental care, were the predominant equilibrium strategists in Caño Maraca. Interestingly, these species comprised similar percentages of the fish assemblages at all three locations, and some were among the most common fishes in certain samples. In theory, the advantage of the equilibrium life history strategy is enhancement of survival of early life stages and recruitment in environmental settings where resource limitation and/or predation have significant influences (Pianka, 1970; Winemiller, 1989a; Winemiller, Rose, 1992). Although Caño Maraca fishes classified as equilibrium strategists do not possess the capacity for large pulses in recruitment under environmental conditions favorable for early life stage survival and growth, they nonetheless should experience less seasonal and inter-annual variation in population abundance. Long-term research at Caño Maraca that collects and analyze long-term abundance data, standardized according to gear type and effort, could test ideas about the relative advantages and disadvantages of alternative life history strategies in relation to environmental variation. Unfortunately, the current socioeconomic and political situation in Venezuela poses a great challenge for field research in the Venezuelan Llanos.

Metacommunity models. In Caño Maraca, fish movements and population dynamics respond to seasonal changes in environmental conditions along the longitudinal fluvial gradient. Results from the current study indicate that the creek's metacommunity structure derives from the combined influences of all four of the metacommunity models proposed by Leibold et al. (2004). Species sorting occurs when dispersal dynamics involve a significant component of habitat selection, whereby species tend to colonize and reside in the most suitable habitat patches within the landscape mosaic. This appears to be the case for most Caño Maraca fishes, for example, P. apolinari restricted to suitable habitat at Naciente, periodic strategists migrating to the Estero wetland for spawning, and fishes migrating out of the wetland to seek dry season refuges, especially within deeper channel reaches, such as Puente, located downstream.

The mass effects model invokes source-sink metapopulation dynamics, with areas of favorable habitat exporting surplus individuals to areas with habitat unsuitable to sustain a local population subunit. At certain scales of space and time, this model also applies to the fish metacommunity of Caño Maraca. For example, the Estero wetland undoubtedly exports recruits to other locations within the drainage network, yet also sustains resident fishes. In addition to these resident fishes (e.g., most cichlids and loricariids, the killifish $R$. maculipinnis, and other small opportunistic strategists), several species entered the wetland to spawn during the wet season. This latter group is comprised mostly of periodic strategists, including headstanders (Leporinus friderici (Bloch, 1794), Schizodon scotorhabdotus Sidlauskas, Garavello, Jellen, 2007), piranhas (Pygocentrus cariba (Humboldt, 1821), Serrasalmus spp.), weakly electric gymnotiforms (e.g., Adontosternarchus devenanzii Mago-Leccia, Lundberg, Baskin, 1985, Rhamphichthys pantherinus Castelnau, 1855), and catfishes (e.g., Ageneiosus magoi Castillo, Brull G., 1989). Other species were captured at the Estero site in large numbers, but no small juveniles were ever captured; these species apparently migrate into the site only to exploit food resources. For example, the coporo (Prochilodus mariae Eigenmann, 1922) is a migratory prochilodontid that was common in at the Estero site during the wet season and well into the dry season, and most of these individuals were subadults that apparently migrated upstream from floodplains located further downstream within the Rio Guanare-Orinoco Basin (Barbarino-Duque et al., 1998).

The patch dynamics model also could be invoked to explain fish metacommunity structure and dynamics at Caño Maraca. Patch dynamics occur when local habitat disturbances and recovery influence the colonization and coexistence by species with different life history strategies and competitive abilities. The model predicts that opportunistic species (r-strategists sensu Pianka, 1970) should colonize and dominate habitat patches during initial stages following a significant disturbance, but with habitat succession and the arrival of more species, more competitive species become predominant to the exclusion of opportunistic species that are superior colonizers but fare poorly in habitats saturated with species from the regional pool. In a dynamic landscape containing a habitat mosaic, there always will be habitat patches and local species assemblages at various stages of succession, with the overall effect of enhancing metacommunity diversity. The level of diversity depends on the relative scales and rates of disturbance, habitat recovery, dispersal, and competitive exclusion. Seasonal changes of Caño Maraca, particularly in the middle and lower reaches, include major habitat disturbances (e.g., desiccation, hypoxia) that reduce fish diversity at the patch scale. Seasonal movements in response to changing conditions clearly influence fish distributions and local species assemblages along the entire longitudinal gradient of the creek, and fish assemblages probably conform to the patch-dynamics model whereby local assemblages contain species with certain ecological attributes depending on the time elapsed since the last disturbance and connectivity within the landscape mosaic. In an experimental study of fish assemblages inhabiting habitat patches in a Neotropical blackwater river, Arrington et al. (2005) found random patterns of species association during early stages of patch colonization, and increasingly non-random patterns of co-occurrence as species accumulated on patches with time. 
Whereas, patterns of presence or absence of many species likely conform to one or more of the three metacommunity models as described above, many species occurrences at a given location during a given period are probably random. Some captured specimens likely were vagrants that were passing through the habitat while seeking more suitable areas for feeding or spawning. Some examples of likely vagrants, species with a single collection record at the Estero site, include Acestrorhynchus microlepis (Jardine, 1841), Colossoma macropomum (Cuvier, 1816), Piaractus brachypomus (Cuvier, 1818), B. whitei, Astyanax integer Myers, 1930, Callichthys callichthys (Linnaeus, 1758), and Crenicichla geayi Pellegrin, 1903. Similarly, species at the other locations also were likely vagrants (e.g., long-distance migratory species, $B$. whitei and Salminus hilarii Valenciennes, 1850). In addition, the stranding and subsequent mortality of fishes in shallow water bodies during the dry season likely involves a random component.

In a review of tropical stream fish ecology, Winemiller et al. (2010) reported that most studies interpreted findings in the context of species sorting and mass-effects models. Our findings suggest that all four metacommunity models describe aspects of the fish assemblage of Caño Maraca. Similarly, Jackson et al. (2013) concluded that patch dynamics, species sorting and mass effects models all were consistent with patterns of fish assemblage structure in naturally colonized lagoons in the Oueme River floodplains in West Africa.

Earlier studies showing spatial variation along longitudinal gradients of tropical rivers (e.g., Angermeier, Karr, 1983; Ibarra, Stewart, 1989; Winemiller, Leslie, 1992, Mazzoni, Lobón-Cerviá, 2000) predated development of metacommunity theory and usually interpreted patterns in the context of species sorting. Nonetheless, these earlier studies generally were interpreted from Gleasonian (species respond to environmental gradients independently) or Clementsian (species are distributed along environmental gradients as clusters of coexisting species) perspectives (Winemiller et al., 2010). More recently, Almeida, Cetra (2016) inferred Gleasonian patterns of fish assemblage structure in relation to longitudinal stream gradients within the upper Paranapanema River Basin in the Atlantic Forest region of Brazil. Assemblage structure varied continuously over space, which the authors interpreted as a reflection of partial overlap in species distributions based on tolerances to conditions along environmental gradients.

We found a weak pattern of nestedness (reflecting a sequence of species addition) in Caño Maraca, which was stronger for the upper reach and complicated by seasonal variation in the lower reach. However, our sites were too few to make definitive conclusions about nested assemblage composition. In a study of fish assemblages from dozens of temporary floodplain ponds along the courses of small streams in the Amazon forest, Couto et al. (2018) found a pattern of species addition in the downstream direction. They attributed this nested pattern to differences among pools of potential colonists within adjacent stream channels and increasing lateral connectivity of aquatic habitats along the longitudinal gradient. Species tolerant of stagnant waters and capable of dispersing across shallow habitats occurred in ponds throughout the entire gradient. The lateral dimension of fluvial connectivity is significant for streams of the Western Llanos, because sheet flooding of flat terrain during the wet season provides numerous dispersal routes between drainages, including Caño Maraca, Caño Delgadito and Caño La Ceiba (Fig. 1).

Improved understanding spatial distributions of species and metacommunity dynamics of Llanos fishes is important for biodiversity conservation and fisheries management. Winemiller et al. (1996) emphasized the importance of longitudinal connectivity for fish access to dry-season refuges located in downstream. Barriers to longitudinal migration include dams and gillnets that span the entire channel width, as well as water diversions that dewater channel segments during the dry season. In addition, pollution from sugar cane processing plants and municipal waste poses a severe threat when pulses of degraded water, including water that is severely oxygen depleted, pass downstream to affect habitats that serve as dry-season refuges (Winemiller et al. 1996). The diverse fish fauna of the Western Llanos supports important artisanal fisheries, both subsistence (exploiting species such as A. magoi, Caquetaia kraussii (Steindachner, 1878), and $B$. whitei) and commercial (the coporo, P. mariae, being most important). Given the great diversity of the regional fish fauna and the productivity of its aquatic ecosystems, there also is great potential for development of fisheries for the ornamental fish trade. In addition, the region's fishes are the major food resource for wetland avifaunas and herpetofaunas that are among the most diverse on Earth. Findings from the current study reinforce the idea that seasonal patterns of connectivity within the fluvial landscape of the Western Llanos enable fish stocks to realize their potential demographic resilience.

\section{Acknowledgments}

We thank the Urriola and Strebbin families for access to sites on their properties. We are grateful for assistance with fieldwork from many individuals, including Aniello Barbarino, Oscar de Leon Mata, Leo Nico, Eric Pianka, David Jepsen, Tamara McGuire, John Williams, Hernán López-Fernández, Megan Winemiller and Brent Winemiller. We thank the staff of the Museo de Ciencias Naturales, Universidad Nacional de Los Llanos Occidentales Ezequiel Zamora for access to specimens and field notes. KOW acknowledges financial support from the National Geographic Society and US Fulbright Scholar Exchange Program. Scientific collecting permits were obtained from the Dirección Administración y Desarrollo Pesquero de la Republica de Venezuela. FWK received fellowship support from Brazil's Coordenação de Aperfeiçoamento de Pessoal de Nível Superior (CAPES), and EOLD received fellowship support from Colombia's COLCIENCIAS. 


\section{References}

Abes SS, Agostinho AA. Spatial patterns in fish distributions and structure of the ichthyocenosis in the Água Nanci stream, upper Paraná River Basin, Brazil. Hydrobiologia. 2001; 445(13):217-27.

Almeida RS, Cetra M. Longitudinal gradient effects on the stream fish metacommunity. Nat Conservacao. 2016; 14(2):112-19.

Angermeier PL, Karr JR. Fish communities along environmental gradients in a system of tropical streams. Environ Biol Fishes. 1983; 9(2):117-35.

Arrington DA, Winemiller KO, Layman CA. Community assembly at the patch scale in a species rich tropical river. Oecologia. 2005; 144(1):157-67.

Barbarino-Duque A, Taphorn DC, Winemiller KO. Ecology of the coporo, Prochilodus mariae (Characiformes, Prochilodontidae), and status of annual migrations in western Venezuela. Environ Biol Fishes. 1998; 53(1):33-46.

Casatti L. Fish assemblage structure in a first order stream, southeastern Brazil: longitudinal distribution, seasonality, and microhabitat diversity. Biota Neotrop. 2005; 5(1):75-83.

Chao A, Gotelli NJ, Hsieh TC, Sander EL, Ma KH, Colwell RK, Ellison AM. Rarefaction and extrapolation with Hill numbers: a framework for sampling and estimation in species diversity studies. Ecol Monogr. 2014; 84(1):45-67.

Couto TBd'A, Zuanon J, Olden JD, Ferraz G. Longitudinal variability in lateral hydrologic connectivity shapes fish occurrence in temporary floodplain ponds. Can J Fish. Aquat Sci 2018; 75(2):319-28.

Dallas T. 2018. metacom: analysis of the 'Elements of metacommunity structure'. R package version 1.5.0. Available from: https://CRAN.R-project.org/package $=$ metacom

Dufrêne M, Legendre P. Species assemblages and indicator species: the need for a flexible asymmetrical approach. Ecol Monogr. 1997; 67(3):345-66.

Freeman MC, Pringle CM, Jackson CR. Hydrologic connectivity and the contribution of stream headwaters to ecological integrity at regional scales. J Am Water Resour Assoc. 2007; 43(1):5-14.

Gonçalves CS, Braga FMS. Changes in ichthyofauna composition along a gradient from clearwaters to blackwaters in coastal streams of Atlantic forest (southeastern Brazil) in relation to environmental variables. Neotrop Ichthyol. 2012; 10(3):67584.

Goulding M, Venticinque E, Ribeiro MLdB, Barthem RB, Leite RG, Forsberg B, Petry P et al. Ecosystem-based management of Amazon fisheries and wetlands. Fish Fisheries. 2018; Available from: https://doi.org/10.1111/faf.12328

Hsieh TC, Ma KH, Chao A. 2016. iNEXT: iNterpolation and EXTrapolation for species diversity. R package version 2.0.12. Available from: http://chao.stat.nthu.edu.tw/blog/softwaredownload/

Ibarra M, Stewart DJ. Longitudinal zonation of sandy beach fishes in the Napo River basin, eastern Ecuador. Copeia. 1989; 1989(2):364-81.

Jackson AT, Adite A, Roach KA, Winemiller KO. Fish assemblages of an African river floodplain: a test of alternative models of community structure. Ecol Freshw Fish. 2013; 22(2):295-306.

Juen L, Cunha EJ, Carvalho FG, Ferreira MC, Begot TO, Andrade A, Shimano L et al. Effects of oil palm plantations on the habitat structure and biota of streams in Eastern Amazon. River Res Appl. 2016; 32:2081-94.
Legendre P, Gallagher ED. Ecological meaningful transformations for ordination of species data. Oecologia. 2001; 129(2):271-80.

Legendre P, Legendre L. Numerical ecology. 3rd English ed. Amsterdam: Elsevier; 2012.

Leibold MA, Holyoak M, Mouquet N, Amarasekare P, Chase JM, Hoopes MF, Holt RD et al. The metacommunity concept: a framework for multi-scale community ecology. Ecol Lett. 2004; 7(7):601-13.

Lowe-McConnell RH. Ecological studies in tropical fish communities. New York. Cambridge: University Press; 1987.

Lujan NK, Conway KW. Life in the fast lane: a review of rheophily in freshwater fishes. In: Riesch R, Tobler M, Plath M, editors. Extremophile fishes - ecology and evolution of teleosts in extreme environments. Springer; 2015. p.107-136, 297-307(appendix).

Mago-Leccia F. Estudios preliminares sobre la ecología de los peces de los llanos. Acta Biol Venez. 1970; 7(1):71-102.

Matthews WJ. Fish faunal structure in an Ozark stream: Stability, persistence and a catastrophic flood. Copeia. 1986; 1986(2):388-97.

Mazzoni R, Lobón-Cerviá J. Longitudinal structure, density and production rates of a Neotropical stream fish assemblage: the River Ubatiba in the Serra do Mar, southeast Brazil. Ecography. 2000; 23(5):588-602.

Oksanen J, Blanchet G, Friendly M, Kindt R, Legendre P, McGlinn D, Minchin PR et al. 2017. vegan: Community Ecology Package. R package version 2.4-3. Available from: https:// CRAN.R-project.org/package $=$ vegan

Paller MH. Relationships between fish assemblage structure and stream order in South Carolina coastal plain streams. Trans Am Fish Soc. 1994; 123(2):150-61.

Pianka ER. On r- and K-selection. Am Nat 1970; 104(940):592-97.

R Core Team. 2017. R: A language and environment for statistical computing. R Foundation for Statistical Computing, Vienna, Austria. Available from: http://www.Rproject.org

Roberts DW. 2016. labdsv: ordination and multivariate analysis for ecology. R package version 1.8-0. Available from: https:// CRAN.R-project.org/package $=$ labdsv

Schlosser IJ. Fish community structure and function along two habitat gradients in a headwater stream. Ecol Monogr. 1982; 52(4):395-414.

Súarez YR, Petrere M Jr. Environmental factors predicting fish community structure in two neotropical rivers in Brazil. Neotrop Ichthyol. 2007; 5(1):61-68.

Taphorn DC, Lilyestrom CG. Los peces del Módulo "Fernando Corrales" resultados ictiológicos del proyecto de investigación del CON1CIT-PIMA-18. Rev Sci Tecn UNELLEZ. 1985; 3:5585.

Winemiller KO. Patterns of variation in life history among South American fishes in seasonal environments. Oecologia. 1989a; 81(2):225-41.

Winemiller KO. Development of dermal lip protuberances for aquatic surface respiration in South American characid fishes. Copeia. 1989b; 1989(2):382-90.

Winemiller KO. Spatial and temporal variation in tropical fish trophic networks. Ecological Monogr. 1990; 60(3):331-67.

Winemiller KO. Life history strategies and the effectiveness of sexual selection. Oikos. 1992; 63(2):318-27.

Winemiller KO. Preface: Stream fish communities from patch dynamics to intercontinental convergences. In: Gido K, Jackson D, editors. Community ecology of stream fishes: Concepts, Approaches and Techniques. Bethesda: American Fisheries Society; 2010. p.23-28. 
Winemiller KO, Pianka ER. Organization in natural assemblages of desert lizards and tropical fishes. Ecol Monogr. 1990; 60(1):27-55.

Winemiller KO, Leslie MA. Fish communities across a complex freshwater-marine ecotone. Environ Biol Fishes. 1992; 34(1):29-50.

Winemiller KO, Rose KA. Patterns of life-history diversification in North American fishes: implications for population regulation. Can J Fish Aquat Sci. 1992; 49(10):2196-218.

Winemiller KO, Marrero C, Taphorn DC. Perturbaciones causadas por el hombre a las poblaciones de peces de los llanos y del piedemonte Andino de Venezuela. Biollania. 1996; 12:13-48.

Winemiller KO, Agostinho AA, Caramaschi EP. Fish ecology in tropical streams. In: Dudgeon D, editor. Tropical stream ecology. San Diego: Elsevier/Academic Press; 2008. Chapter 5; p.107-146.

Winemiller KO, Flecker AS, Hoeinghaus DJ. Patch dynamics and environmental heterogeneity in lotic ecosystems. J N Am Benthol Soc. 2010; 29(1):84-99.

Wolff LL, Hahn NS. Fish habitat associations along a longitudinal gradient in a preserved coastal Atlantic stream, Brazil. Zoologia. 2017; 34:e12975. https://doi.org/10.3897/zoologia.34.e12975

(c) (i)

Submitted June 08, 2018 Accepted October 21, 2018 by Francisco Araújo 